\title{
In vitro effect of seed bio-priming techniques on seed germination and seedling vigour of few vegetable crops
}

\author{
Rakesh Kumar Jaiman* \\ Department of Plant Protection, College of Horticulture, S.D. Agricultural University, \\ Jagudan, Mehsana -384460 ( Gujarat), India \\ Sanjay Kumar Acharya \\ Department of Vegetable Science, College of Horticulture, S.D. Agricultural University, \\ Jagudan, Mehsana -384460 ( Gujarat), India \\ Naziya P. Pathan \\ Department of Plant Protection, College of Horticulture, S.D. Agricultural University, \\ Jagudan, Mehsana -384460 ( Gujarat), India \\ Amol J. Deshmukh \\ Department of Plant Pathology, College of Agriculture, Navsari Agricultural University, \\ Waghai, Dang-394730 (Gujarat), India \\ Haresh A. Desai \\ Department of Plant Protection, College of Horticulture, S.D. Agricultural University, \\ Jagudan, Mehsana -384460 ( Gujarat), India \\ Parsva K. Patel \\ Department of Plant Protection, College of Horticulture, College of Horticulture, S.D. \\ Agricultural University, Jagudan, Mehsana -384460 ( Gujarat), India \\ Anilkumar Umedbhai Amin \\ College of Horticulture, S.D. Agricultural University, Jagudan, Mehsana -384460 ( Gujarat), \\ India \\ *Corresponding author. Email: jaimanrs74@gmail.com
}

\author{
Article Info \\ https://doi.org/10.31018/ \\ jans.v12i4.2422 \\ Received: November 3, 2020 \\ Revised: December 10, 2020 \\ Accepted: December 13, 2020
}

\section{How to Cite}

Jaiman R. K. et al. (2020). In vitro effect of seed bio-priming techniques on seed germination and seedling vigour of few vegetable crops. Journal of Applied and Natural Science, 12(4):702 - 709. https://doi.org/10.31018/jans.v12i4.2422

\begin{abstract}
Bio-priming can also be viewed as a new technique of seed treatment using biological agents to stimulate germination of seed and growth of the plant and further protecting the seed from soil-and seed-borne pathogens. The present investigation was carried out in vitro conditions on seed germination and seedling vigour of few vegetable crops viz. tomato (Solanum lycopersicum L.), brinjal (Solanum melongena L.), onion (Allium cepa L.) and chilli (Capsicum annuum L.), during 2015 and 2016. The treatments comprised viz. T1: Non primed seeds (Control), T2: Seed treatment with Carbendazim 2.5g/kg seed, T3: Hydropriming for $6 \mathrm{hrs}$, T4: Hydro-priming for $12 \mathrm{hrs}$, T5: Hydro-priming for $18 \mathrm{hrs}$, T6: Biopriming with Trichoderma viride for 6 hrs, T7: Biopriming with T.viride for 12 hrs, T8: Biopriming with T.viride for 18 hrs, T9: Biopriming with Trichoderma harzianum for 6 hrs, T10: Biopriming with T. harzianum for $12 \mathrm{hrs,} \mathrm{T11:} \mathrm{Biopriming} \mathrm{with} T$. harzianum for $18 \mathrm{hrs}$, T12: Biopriming with Pseudomonas fluorescens for $6 \mathrm{hrs}$, T13: Biopriming with $P$. fluorescens for $12 \mathrm{hrs}$ and T14: Biopriming with $P$. fluorescens for 18 hrs. The results revealed that maxiumum germination percentage (92.92, 90.77,83.00 and 86.33), seedling length (32.38 cm, 29.35 $\mathrm{cm}, 31.75$ and $31.60 \mathrm{~cm})$, seedling fresh weight $(2.07 \mathrm{~g}, 4.01 \mathrm{~g}, 3.05 \mathrm{~g}$ and $2.04 \mathrm{~g})$, seedling dry weight $(0.42 \mathrm{~g}, 0.86 \mathrm{~g}, 0.62 \mathrm{~g}$ and $0.42 \mathrm{~g}$ ) and seedling vigour index $\left(3008.11,2664.00,2635.00\right.$ and 2728.00 ) were recorded in $\mathrm{T}_{10}$ (bio priming with $T$. harzianum for $12 \mathrm{hrs}$ ) in tomato (S. lycopersicum L.), brinjal (S. melongena L.), onion (A. cepa L.) and chilli (C. annuum L.), respectively. Thus, it indicated that priming of seeds of these crops with $T$. harzianum/P. fluorescens/ T. viride for 12 hrs was very effective with respect to their vegetative growth along with the quality yield.
\end{abstract}

Keywords: Bio-priming, Brinjal, Chilli, Germination, Onion, Seedling vigour, Tomato

\section{INTRODUCTION}

Horticultural production is primarily involved in the intensive use of resources, such as land, water, labour and inputs such as fertilizers and pesticides. The use of such resources in a concentrated space and time has the potential to negatively impact on the local environment and workers welfare (Wainwright et al., 2014). The use of pesticides and fertilizers are of major concern and minimize their impact on the environment and safer alternatives have been sort. The use 
of microbes has been reported over the years to promote growth and yield commonly termed as "biofertilizers". A group of soil-based bacterium that promotes growth has been termed as "Plant GrowthPromoting Rhizobacteria (PGPR)". As a consequence, PGPR has the potential to enhance plant health and promote the rate of plant growth without environmental contamination (Vejan et al.,2016). A range of PGPR have been studied, including the species Pseudomonas, Bacillus, Enterobacter, Klebsiella, Azobacter, Variovorax, Azosprillum and Serratia (Glick, 2012). However, the commercial utilization of PGPR in the agriculture industry is disappointing. The successful use of PGPRs is dependent on many factors, including survival of the organism on the seed as well as soil. The interaction with the microflora in the soils and crop, it provides consistent results across a range of environments. However, PGPRs work in different ways and need to understand successful adoption. An important and integral component is to apply the PGPR in an efficient manner, compatible with current agricultural practice. Treating seeds with PGPR offers an economical and efficient application method (O'Callagham, 2016).

Seed treatment with bio-control agents along with priming agents may serve as an important means of managing many soils as well as seed-borne problems and promote the growth of the plant, the process known as "bio-priming". Biological agents such as beneficial fungi and bacteria are used in bio-priming, which includes Trichoderma and Pseudomonas (Sharma et al., 2018). Seed priming using osmotic solutions has been around for many decades (Heydecker et al., 1975). The concept was extended to hydro priming in cereal and legume crops and the technique of "on farm" priming has been revived (Harris et al., 2001). More recently the term Bio-priming has been adopted where the seed is immersed in a microbial suspension for a predetermined period, followed by drying of the seed to prevent the onset of germination. It is most appropriate for low-medium volume, high-value crops, such as vegetable seed (O'Callagham, 2016). Biopriming treatment is potentially prominent to induce profound changes in plant characteristics and to encourage more uniform seed germination and plant growth associated with fungi and bacteria coatings (Entesari et al., 2013).

Major vegetable crops like tomato, chilli, brinjal, onion etc were hampered with a load of pathogenic seed microflora. These lead to a number of nurseries (viz., seed rot, pre, post-emergence damping-off) and field diseases. The infected seeds thus used are responsible not only for the poor germination seedlings stand but also for the carryover of pathogens to the field. Moreover, the germination time of most of the vegetable crops is very high viz., tomato (Solanum lycopersicum L.), brinjal (Solanum melongena L.), onion (Allium cepa L.) and chilli (Capsicum annuum L.) as compared to field crops which lead to non-uniform seedling stand and low vigour seedlings. Thus, the present study was conducted to find out a suitable bio-priming method with an optimum priming time interval under in vitro conditions for these vegetable crops.

\section{MATERIALS AND METHODS}

An experiment was conducted at College of Horticulture, S.D. Agricultural University, Jagudan (Mehsana) Gujarat during 2015 and 2016 in laboratory condition (in vitro). Fourteen treatments using the strains viz. Trichoderma viride, T. harzianum and Pseudomonas fluorescens (Table 1) were replicated thrice. The strains of these organisms were procured from the Bio -control Laboratory, Department of Plant Pathology, Junagadh Agricultural University, Junagadh 362001 (Gujarat) India. The cultivar Anand Tomato-2, Gujarat Oblong Brinjal-2, Agrifound Light Red and Gujarat Chilli-3 were used. Healthy seeds (100) were thoroughly sterilized with $0.1 \% \mathrm{HgCl}_{2}$ for 2-5 minutes and 2 -3 times washed with distilled water before use in experiments. The seeds were soaked in a double quantity of water for the given time of interval and the formulated product of biopesticide @ 10g/kg seed (solid)) were mixed to make a heap of the treated seeds, and the heap was covered with a moist jute sack to maintain high humidity and then incubated such seeds in high humidity in a shady place for $12 \mathrm{hrs}$. The bioagents adhered to the seeds were grown and formed a protective layer on seed coat. Such seeds were dried under shade and such seeds were used further to see the effect in vitro trial and evaluated by Paper towel method (ISTA, 2013).

Observations were recorded on germination percentage $(\%)$, seedling lengths $(\mathrm{cm})$, seedling fresh weight (g), seedling dry weight (g) and Seedling vigour index were observed as per standard methods and calculated by the Germination Percentage (Bekendam Jan and Grob Regula, 1979) formula:

Germination percentage $(\mathrm{GP})=\mathrm{n} / \mathrm{N} \times 100 \quad \ldots$. Eq. 1

whereas, $n=$ number of seeds that were germinated, $\mathrm{N}$ : total number of seeds in each experiment

Seedling Length $(\mathrm{cm})=$ Plumule length + Radical length ......Eq.2

Seedling Fresh Weight $(\mathrm{g})=$ Plumule weight + Radical weight (Five plant were taken then averaged out).

Seedling Dry Weight $(\mathrm{g})=$ Plumule weight + Radical weight (Five plant were taken then oven dry it, averaged it).

Vigour Index = Seedling vigor index was calculated by (Abdul-Baki and Anderson, 1973) formula:

Seedling vigor index=Seedling length $(\mathrm{cm}) \times \%$ germination .........Eq. 3

Whereas, Seedling length $=$ Root length + Shoot length (cm)

\section{RESULTS AND DISCUSSION}

Germination percentage (\%): Results revealed 
Table 1. Treatments details used for bio priming.

\begin{tabular}{ll}
\hline $\begin{array}{l}\text { Treatment } \\
\text { notation }\end{array}$ & Treatment details \\
\hline $\mathrm{T}_{1}$ & Non primed seeds (Control) \\
$\mathrm{T}_{2}$ & $\begin{array}{l}\text { Seed treatment with Carbendazim } 2.5 \mathrm{~g} / \\
\text { kg seed }\end{array}$ \\
$\mathrm{T}_{3}$ & Hydro-priming for $6 \mathrm{hrs}$ \\
$\mathrm{T}_{4}$ & Hydro-priming for $12 \mathrm{hrs}$ \\
$\mathrm{T}_{5}$ & Hydro-priming for $18 \mathrm{hrs}$ \\
$\mathrm{T}_{6}$ & Biopriming with $T$. viride for $6 \mathrm{hrs}$ \\
$\mathrm{T}_{7}$ & Biopriming with $T$. viride for $12 \mathrm{hrs}$ \\
$\mathrm{T}_{8}$ & Biopriming with $T$. viride for $18 \mathrm{hrs}$ \\
$\mathrm{T}_{9}$ & Biopriming with $T$. harzianum for $6 \mathrm{hrs}$ \\
$\mathrm{T}_{10}$ & Biopriming with $T$. harzianumfor $12 \mathrm{hrs}$ \\
$\mathrm{T}_{11}$ & Biopriming with $T$. harzianumfor $18 \mathrm{hrs}$ \\
$\mathrm{T}_{12}$ & Biopriming with $P$. fluorescens for $6 \mathrm{hrs}$ \\
$\mathrm{T}_{13}$ & Biopriming with $P$. fluorescens for $12 \mathrm{hrs}$ \\
$\mathrm{T}_{14}$ & Biopriming with $P$. fluorescens for $18 \mathrm{hrs}$ \\
\hline
\end{tabular}

(Table 2) that there was a significant difference at 5 per cent level of significance in germination per cent during individual year as well as in pooled for all the crops viz. tomato (S. lycopersicum ), brinjal ( $S$. melongena ), onion ( $A$. cepa ) and chilli (C. annuum ), The maximum germination per cent (92.92) was observed in $T_{10}$, i.e. biopriming with $T$. harzianum for 12 hrs followed by (90.75) $\mathrm{T}_{13}$ (biopriming with $P$. fluorescens for $12 \mathrm{hrs})$. However, minimum germination per cent (70.50) was recorded in hydro-priming for 18 hrs $\left(T_{5}\right)$ followed by (72.42) non-primed seeds (control). Similar trends were observed for all the crops studied in pooled as well as individual years also. The primed seed might have showed higher field emergence due to the production of microbial seed leachates that provide the source of carbon and nitrogen in the initial few days but there after the translocation of quantum and nature (qualitative and quantitative) of photosynthates in the form of root exudates would determine the proliferation of the microbial inoculants. In the present study, enhancement of seed germination and plant growth promotion in tomato, brinjal, onion and chilli might be due to production of growth regulators by $T$. spp. and $P$. fluorescens. This study is in close agreement with the results reported by Begum et al. (2010) with the biopriming of $P$. aeruginosa resulted in enhancement of seed germination and healthy seedling stand ranging from $32.4 \%$ to $60.0 \%$ and $56.0 \%$ to $73.9 \%$, respectively in soybean (Glycine max) and Sharma et al. (2018) in soybean observed maximum field emergence $(88.47 \%)$ with Pseudomonas fluorescens bio-primed seeds followed by Pseudomonas fluorescens + Trichoderma harzianum $(82.43 \%)$ and phosphorous solubilizing bacteria (74.98\%), Reddy et al. (2011) in chickpea primed seeds with $T$. viride and $P$. fluorescens significantly improved seedling emergence of 96 and $98 \%$, respectively and Yadav et al. (2013) in chickpea and rajma found better results for higher germination percentage and plant growth when combined priming with Pseudomonas fluorescens, Trichoderma asperellum and Rhizobium sp., in both the crops.

Seedling length $(\mathbf{c m})$ : Data showed (Table 3 ) that there were statistically significant differences at 5 per cent level of significance for seedling length in the individual year as well as pooled in all the crops viz. tomato, brinjal, onion and chilli. The maximum seedling length $(32.38 \mathrm{~cm})$ was observed in $T_{10}$, i.e. biopriming with $T$. harzianum for $12 \mathrm{hrs}$ followed by $(31.71 \mathrm{~cm}) \mathrm{T}_{13}$ i.e. biopriming with $P$. fluorescens for $12 \mathrm{hrs}$ and minimum seedling length $(24.35 \mathrm{~cm})$ was observed in $\mathrm{T}_{5}$ i.e. hydro-priming for $18 \mathrm{hrs}$ followed by $(24.75 \mathrm{~cm}) \mathrm{T}_{1}$ i.e. non primed seeds (control) in pooled data. Similar trends were observed in all the crops in pooled as well as individual years. This increase in plant growth might be due to rhizobacterial action of auxin production and phosphate solubilization. Microbial auxin production and phosphate solubilization would have played a role in better plant growth, including plant height. The elongation of plant height through microbial inoculants has already been reported by a number of workers. Similar findings in soybean have previously been reported by Yehia et al. (1994) and they observed maximum percentage of seedling emergence, plant height, fresh and dry weight, number of nodules, total $\mathrm{N}$ and total protein contents of the plants with the priming of $T$. harzianum and Fath El-bab et al. (2013) primed green bean seeds with either $T$. harzainum or $T$. viride were the most superior treatments for maximum plant height and plant branches during two seasons.

Seedling fresh weight $(\mathbf{g})$ : It is revealed from the table (Table 4) that there was a significant difference in seedling fresh weight during the individual year as well as in pooled in all four crops viz. tomato, brinjal, onion and chilli. Maximum seedling fresh weight (2.07g) was observed in $\mathrm{T}_{10}$ i.e. biopriming with $T$. harzianum for 12 hrs followed by (2.02g) $\mathrm{T}_{13}$ i.e. biopriming with $P$. fluorescens for 12 hrs and minimum seedling fresh weight $(1.03 \mathrm{~g})$ was observed in $\mathrm{T}_{5}$ i.e. hydropriming for $18 \mathrm{hrs}$ followed by $(1.10 \mathrm{~g}) \mathrm{T}_{1}$, i.e. non primed seeds (control) in pooled data. Similar trends were observed in all the crops in pooled as well as individual years. Coated seeds by bioagents and seed bio priming cause a significant increase of vegetative growth of many crops (El-Mohamedy et al., 2006). The enhancing effect of bio -priming on increasing vegetative growth parameter of these vegetable crops might be attributed to its efficiency in supplying the biologically fixed nitrogen, dissolved immobilized induce exudates of some hormonal substances like gibberellic acid, cytokinins and auxins which could stimulate nutrients absorption as well as photosynthesis process which subsequently increased growth. These 


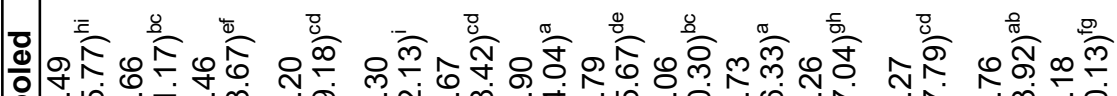

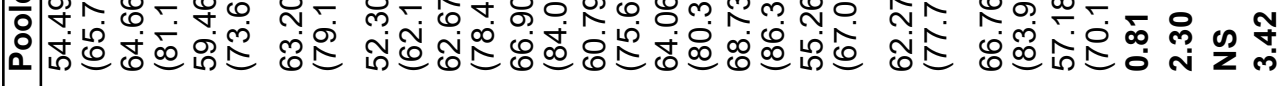

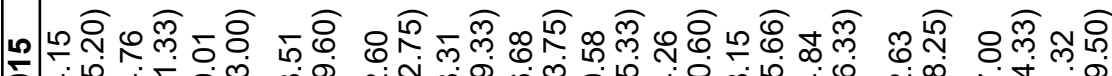

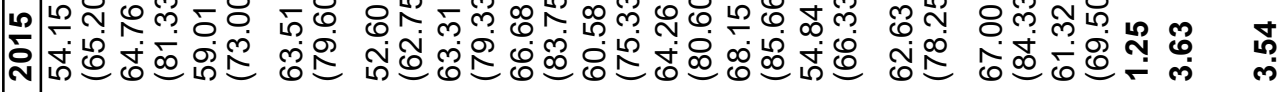

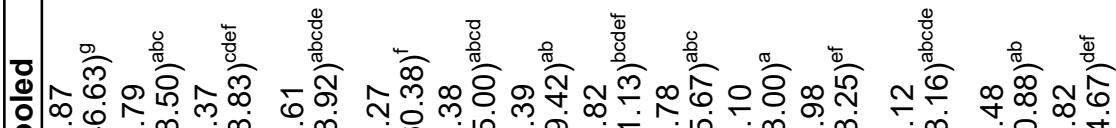

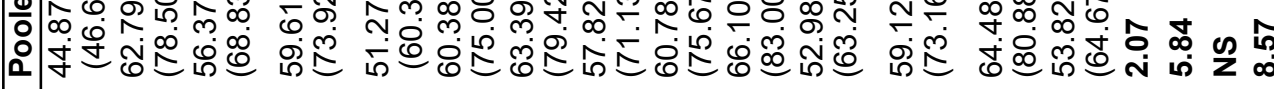

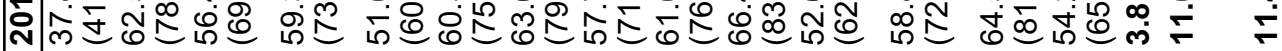

n)

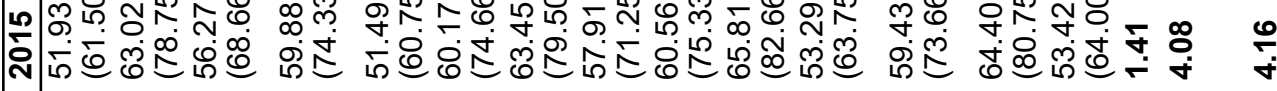

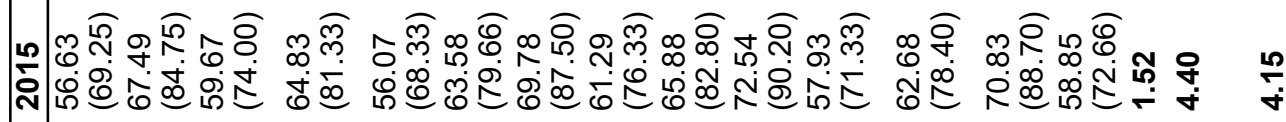

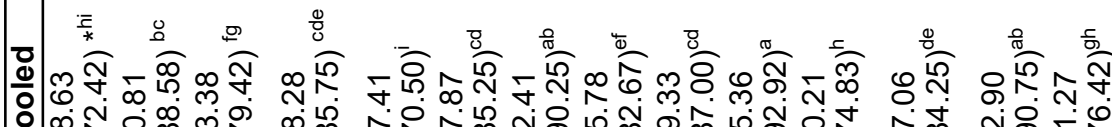
م. 8 है은

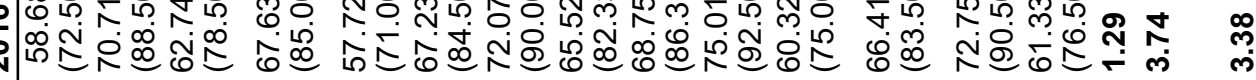

n)

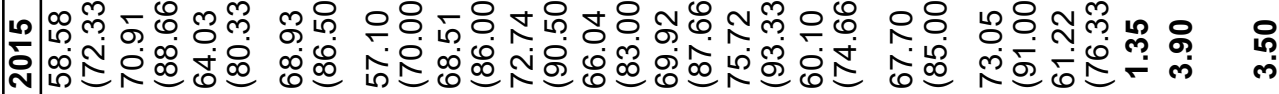




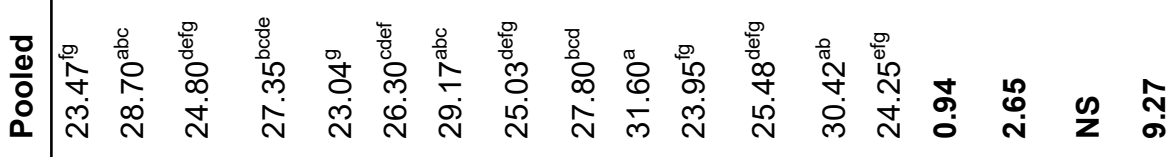

U一

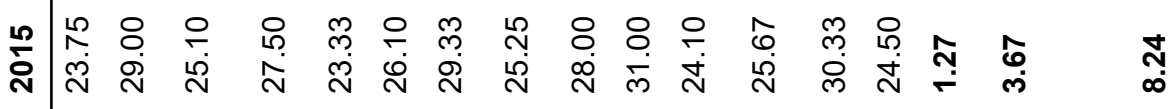

ఫ

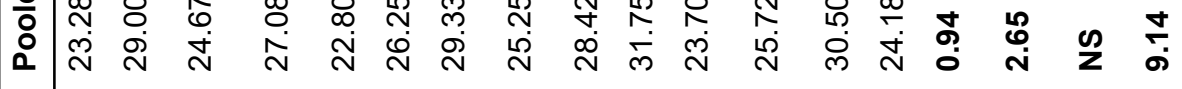

$\stackrel{\bar{\partial}}{\frac{\bar{\sigma}}{\sigma}}$

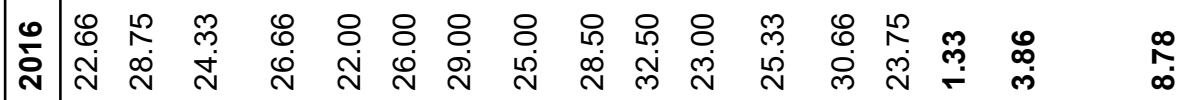

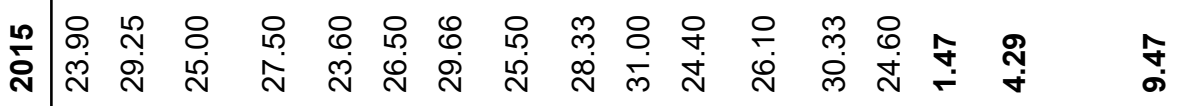

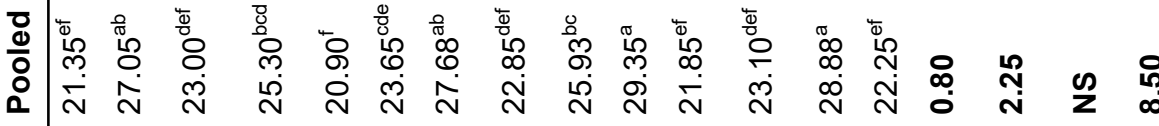

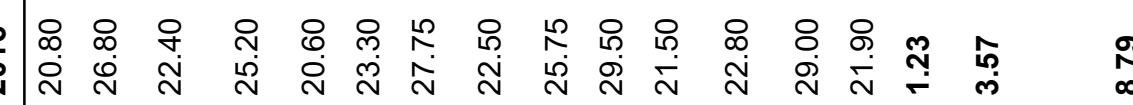

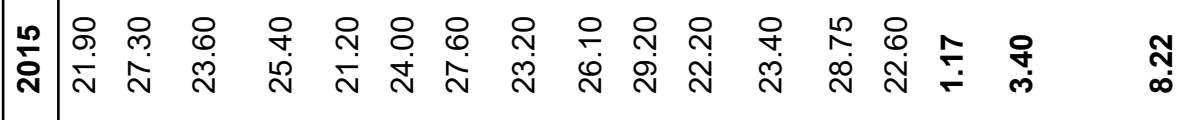

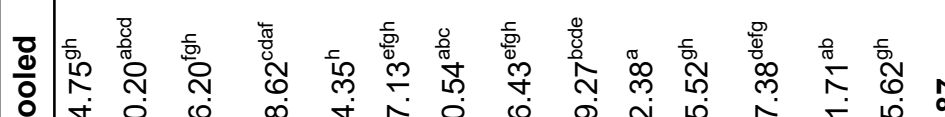

@ d

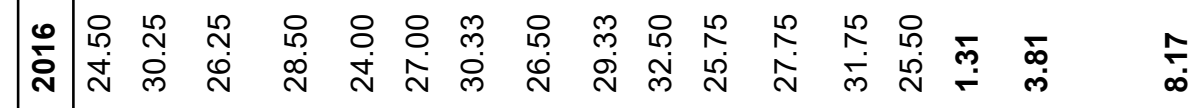

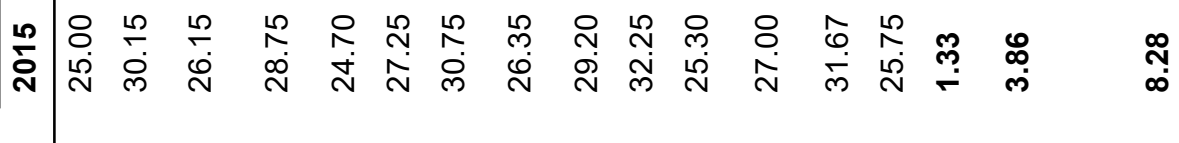




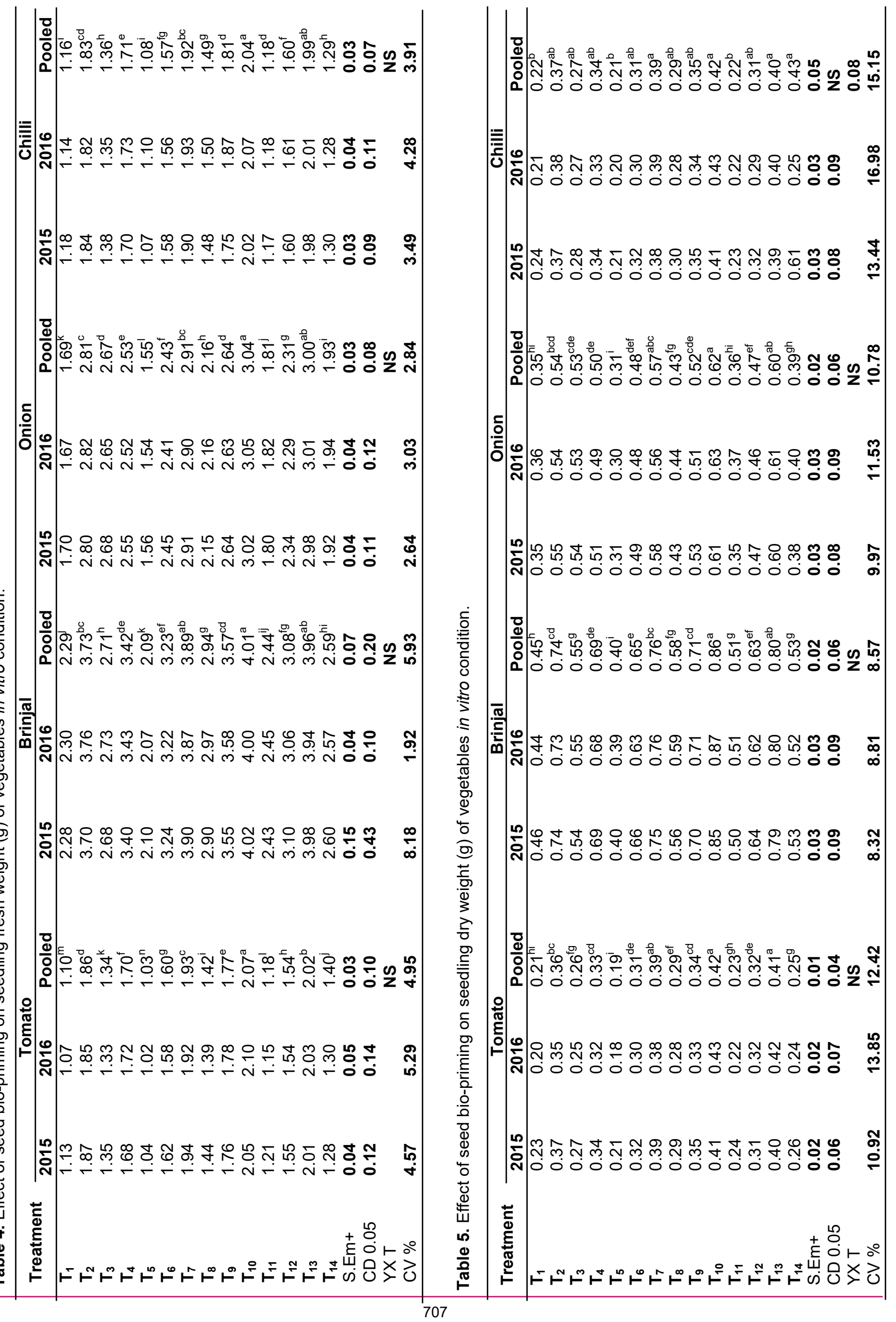




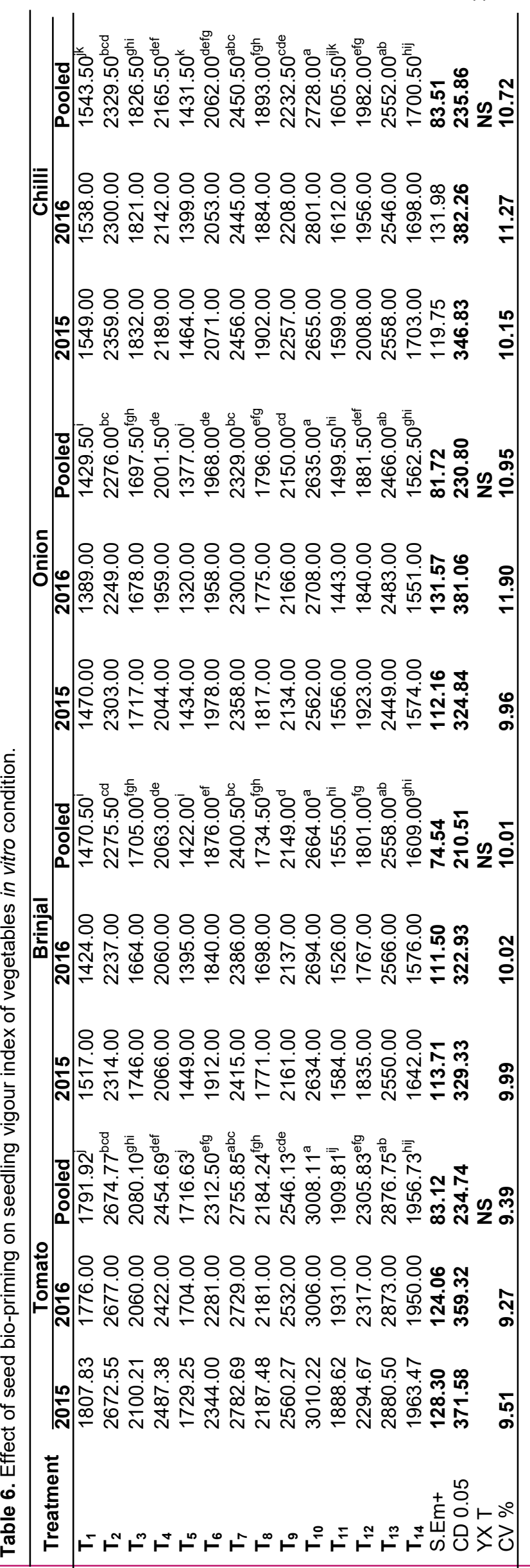

results are in accordance with Mona et al. 2017 observed primed soybean seeds with either $T$. harzainum or $B$. subtilis were superior for greatest plant height, plant branches and fresh and dry weight of root and shoot plant during the two seasons, Harman et al.1989 treated seeds of sweet corn with $T$. harzianum strain resulted in significant increases in plant stand establishment, produced the largest fresh and dry weight and Callan et al. (1991) reported the highest emergence, plant height and fresh weight with biopriming corn seed with $P$. fluorescens

Seedling dry weight $(\mathbf{g})$ : Table 5 indicated that there was a significant difference in seedling dry weight during the individual year as well as in pooled in all four crops viz. tomato, brinjal, onion and chilli. Maximum seedling dry weight $(0.42 \mathrm{~g})$ was observed in $\mathrm{T}_{10}$ i.e. biopriming with $T$. harzianum for $12 \mathrm{hrs}$ which was at par with $(0.41 \mathrm{~g}) \mathrm{T}_{13}$, i.e. biopriming with $P$. fluorescens for $12 \mathrm{hrs}$ and minimum seedling dry weight $(0.19 \mathrm{~g})$ was observed in $T_{5}$ i.e. hydro-priming for $18 \mathrm{hrs}$ and followed by $(0.21 \mathrm{~g}) \mathrm{T}_{1}$, i.e. non primed seeds (control) in pooled and tomato crop. Similar trends were observed in all the crops in pooled as well as individual years. $P$. fluorescens might increase the plant growth promoting activities which help in increasing the seedling dry weight. These results are in conformity with the findings of Moeinzadeh et al.(2010) observed selected strains of $P$. fluorescens (UTPf76 and UTPf86) significantly $(P=0.01)$ increased the root length, shoot height and wet weight of seedlings over the osmopriming in sunflower and Sharifi (2012) noticed seed inoculation with Pseudomonas strain 186 applied in application of $180 \mathrm{~kg} / \mathrm{ha}$ increased grain yield and yield attribute in safflower.

Seedling vigour index: Results depicted (Table 6) that there was a significant difference in seedling vigour index during the individual year as well as in pooled in all four crops viz. tomato, brinjal, onion and chilli. The maximum seedling vigour index (3008.11) was observed in $\mathrm{T}_{10}$ i.e. biopriming with $T$. harzianum for 12 hrs followed by (2876.75) $\mathrm{T}_{13}$ i.e. biopriming with $P$. fluorescens for $12 \mathrm{hrs}$ and minimum seedling vigour index (1716.63) was observed in $T_{5}$ i.e. hydro-priming for $18 \mathrm{hrs}$ which was at par with (1791.92) $\mathrm{T}_{1}$ i.e. non primed seeds (control) in pooled and tomato crop. Similar trends were observed in all the crops in pooled as well as individual years. Growth promoting bacteria were able to promote the growth and biomass production in different plant species. Pseudomonas spp. promoted plant growth by increasing nutrient absorption (e.g., N, P, K) and providing hormones in the rhizosphere (Díaz et al.,2001; Duda and Orlikowski, 2004).

\section{Conclusion}

It was concluded that seed bio priming with $T$. harzianum/ P. fluorescens/ T. viride for $12 \mathrm{hrs}$. enhanced germination, seedling length, seedling fresh and dry weight and vigour index in tomato (S. lycopersicum ), 
brinjal ( $S$. melongena ), onion ( $A$. cepa ) and chilli ( $C$. annuum ). It is therefore suggested that before sowing the seeds of tomato, brinjal, onion and chilli, the seeds should be treated under in vitro conditions with $10 \mathrm{~g} / \mathrm{kg}$ of $T$. harzianum/ P. fluorescens/ T. viride in 20 $\mathrm{ml}$ distilled water for 12 hours to enhance the vegetative growth of these crops along with quality yield.

\section{ACKNOWLEDGEMENTS}

This study was carried out with financial support from S.D. Agricultural University and Government of Gujarat, Gandhinagar.

\section{Conflict of interests}

The authors declare that they have no conflict of interests.

\section{REFERENCES}

1. Abdul-Baki, A. A. and Anderson, J. D. (1973). Vigour determination in soybean seeds by multiple criteria. Crop Sci.. 13(6):630-633.

2. Begum, M. M., Meon, Sariah., Puteh, Adam., Ahmad, M., Adidin, Z., Rahman, M.A. and Siddiqui, Y. (2010). Field performance of bioprimed seeds to suppress Colletotrichum truncatum causing damping off and seedling stand of soybean. Biological Control. 53: 18-23.

3. Bekendam, Jan and Grob, Regula (1979). Hand book for seedling evaluation. International Seed Testing Association, Zurich, Switzerland.

4. Callan, N.W., Mathre, D. T. and Miller, J.B. (1991). Yield performance of sweet corn seed bio-primed and coated with Pseudomonas fluorescence AB 254. Hort. Science. 26 (9):1163-1165.

5. Díaz, P., Almaraz-Suárez, F.C. and Alcántara, J. (2001) Inoculation of plant growth promoting bacteria in Lettuce. Terra. 19: 327-333.

6. Duda, B. and Orlikowski, L. B. (2004) Rhizoctonia solani on coniferous seedlings in forest nurseries. Journal of Plant Protection Research. 44 (3): 175-180.

7. El-Mohamedy, R. S. R, Abd -Alla, M.A. and Badiaa, R.I. ( 2006). Soil amendment and bio -priming treatments as alternative fungicides for controlling root rot diseases on cowpea plants in Nobria province. Research Journal of Agriculture and Biological Sciences.2 (6):391-398.

8. Entesari, M., Sharifzadeh, F., Ahmadzadeh, M. and Farhangfar, M. (2013). Seed biopriming with Trichoderma species and Pseudomonas fluorescens on growth parameter, enzyme activity and nutritional status of soybean. International Journal of Agronomy and Plant Production. 4 (4) : 610-619.

9. Fath, El-bab, T. Sh., Riad, S.R. and El-Mohamedy. 2013. Bio-priming seed treatment for suppressive root rot soil borne pathogens and improvement growth and yield of green bean (Phaseulas vulgaris L.) in new cultivated lands. Journal of Applied Sciences Research. 9(7): 43784387.

10.Glick, B.R. (2012). Plant Growth-Promoting Bacteria Mechanisms and Application. Hindawi Publishing Corporation. Scientifica: Waterloo, Canada. 1-16.
11.Harman, G.F., Taylor, A.G. and Stasz, T.E. (1989). Combining effective strains of Trichoderma harzanum and solid matrix priming to improve biological control seed treatment. Phytopathology. 73:631-637.

12.Harris, D., Pathan, A. K., Gothkar, P., Joshi, A., Chivasa, W. and Nyamudeza, P. (2001). On-farm seed priming: using participatory methods to revive and refine a key technology. Agricultural Systems 69. 151-164.

13. Heydecker, W., Higgins, J. and Jumer, Y. J. (1975). Invigoration of seeds. Seed Science Technology. 3: 881-888.

14.ISTA. (2013). International Rules for Seed Testing. The International Seed Testing Association,Basssersdorf, Switzerland.

15.Moeinzadeh, A., Sharif-Zadeh, F. and Ahmadzadeh, M. (2010). Biopriming of sunlower (Helianthus annuus L.) seed with Pseudomonas fluorescens for improvement of seed invigoration and seedling growth. Aust. J. Crop Sci.4 (7):564.

16.Mona, M. M. R., Ashour, A.M.A., El-Mohamedy, R.S.R., Morsy, A. A. and Hanafy, E.K.(2017).Seed bio priming as biological approach for controlling root rot soil born fungi on soybean (Glycine max L.) plant. International Journal of Agricultural Technology. 13(5):771-788.

17.O'Callagham, M. (2016) Microbial inoculation of seed for improved crop performance: issues and opportunities. Appl Microbiol Biotechnol, 100: 5729-5746.

18.Reddy, A.S.R., Madhavi, G.B., Reddy, K.G., Yellareddygari, S.K., and Reddy, M.S.( 2011). Effect of seed biopriming with Trichoderma viride and Pseudomonas fluorescens in chickpea (Cicer arietinum) in Andhra Pradesh. Plant growth-promoting rhizobacteria (PGPR) for sustainable agriculture, 324-429.

19.Sharma, P., Bhatt, A. and Bhim, J. (2018). Effect of seed bio-priming with microbial inoculants on plant growth, yield and yield contributing characters in soybean [Glycine max (L.) Merril]. International J. of Economic Plants. 5(2):5358.

20.Sharifi, R.S. (2012). Study of nitrogen rates effects and seed biopriming with PGPR on quantitative and qualitative yield of Safflower (Carthamus tinctorius L.). Tech. J. Eng. Appl. Sci.2:162-6.

21.Vejan, P., Abdullah, R., Khadiran, T., and Salmah, I. (2016) Role of Plant Growth Promoting Rhizobacteria in Agricultural Sustainability - A review. Molecules. 21, 573, $1-17$.

22.Wainwright, H., Jordan, C., and Day, H. (2014). Environmental Impact of Production Horticulture. In Horticulture: Plants for People and Places, Volume 1. (Eds, Dixon, G.R. and Aldous, D.E.), Springer Science, Dordrecht 1, 503-522.

23.Yadav, S.K., Dave, A., Sarkar, A., Singh, H.B. and Sharma, B.K. (2013). Co-inoculate biopriming with Trichoderma, Pseudomonas and Rhizobium improves crop growth in Cicer arietinum and Phaseolus vulgaris. International Journal of Agriculture Environment and Biotechnology. 6 (2): 255-259.

24.Yehia, A.H., Abd-El.Kader, D.A., Salem, D. E. and SayadAhmed, A.A. (1994). Biological soil treatment with Trichoderma harzianum to control brown stem rot of soybean in Egypt. Egyptian Journal of Phytopatology. 22(2): 143157. 